\title{
Reduced peak oxygen uptake and implications for cardiovascular health and quality of life in patients with schizophrenia
}

\author{
Jørn Heggelund ${ }^{1,2,3^{*}}$, Jan Hoff ${ }^{4,5+}$, Jan Helgerud ${ }^{4,6,7 \dagger}$, Geir E Nilsberg ${ }^{3+}$ and Gunnar Morken ${ }^{1,3+}$
}

\begin{abstract}
Background: Peak oxygen uptake $\left(\mathrm{VO}_{2 \text { peak }}\right)$ is a strong predictor of cardiovascular disease (CVD) and all-cause mortality, but is inadequately described in patients with schizophrenia. The aim of this study was to evaluate treadmill VO $\mathrm{V}_{2 \text { peak, }}$ CVD risk factors and quality of life (QOL) in patients with schizophrenia (ICD-10, F20-29).

Methods: 33 patients, 22 men (33.7 \pm 10.4 years) and 11 women (35.9 \pm 11.5 years), were included. Patients $\mathrm{VO}_{\text {2peak }}$ were compared with normative $\mathrm{VO}_{2 \text { peak }}$ in healthy individuals from the Nord-Trøndelag Health Study (HUNT). Risk factors were compared above and below the $\mathrm{VO}_{2 \text { peak }}$ thresholds; 44.2 and $35.1 \mathrm{ml} \cdot \mathrm{kg}^{-1} \cdot \mathrm{min}^{-1}$ in men and women, respectively.

Results: $\mathrm{VO}_{2 \text { peak }}$ was $37.1 \pm 9.2 \mathrm{ml} \cdot \mathrm{kg}^{-1} \cdot \mathrm{min}^{-1}$ in men with schizophrenia; $74 \pm 19 \%$ of normative healthy men ( $\mathrm{p}<$ 0.001). $\mathrm{VO}_{\text {2peak }}$ was $35.6 \pm 10.7 \mathrm{ml} \cdot \mathrm{kg}^{-1} \cdot \mathrm{min}^{-1}$ in women with schizophrenia; $89 \pm 25 \%$ of normative healthy women (n.s.). Based on odds ratio patients were $28.3(95 \% \mathrm{Cl}=1.6-505.6)$ times more likely to have one or more CVD risk factors if they were below the $\mathrm{VO}_{2 \text { peak }}$ thresholds. $\mathrm{VO}_{\text {2peak }}$ correlated with the SF-36 physical functioning $(r=0.58)$, general health $(r=0.53)$, vitality $(r=0.47)$, social function $(r=0.41)$ and physical component score $(r=0.51)$.

Conclusion: Men with schizophrenia have lower $\mathrm{VO}_{2 \text { peak }}$ than the general population. Patients with the lowest $\mathrm{VO}_{2 \text { peak }}$ have higher odds of having one or more risk factors for cardiovascular disease. $\mathrm{VO}_{2 \text { peak }}$ should be regarded as least as important as the conventional risk factors for $\mathrm{CVD}$ and evaluation of $\mathrm{VO}_{2 \text { peak }}$ should be incorporated in clinical practice.
\end{abstract}

\section{Background}

Patients suffering from schizophrenia have a mortality risk that is two to three times that of the general population and the leading cause of death is cardiovascular disease (CVD) [1,2]. Although, multifactor causes have been identified, reduced cardiorespiratory fitness has probably been overlooked as a risk factor for CVD in patients with schizophrenia [3].

Cardiorespiratory fitness, measured as peak oxygen uptake $\left(\mathrm{VO}_{2 \text { peak }}\right)$ is a strong predictor of CVD and allcause mortality $[4,5]$. Improvements in $\mathrm{VO}_{2 \text { peak }}$ have indicated reduced risk of CVD, coronary heart disease and all cause mortality [5]. $\mathrm{VO}_{2 \text { peak }}$ is often a stronger

\footnotetext{
* Correspondence: Jorn.Heggelund@ntnu.no

+ Contributed equally

${ }^{1}$ Norwegian University of Science and Technology, Faculty of Medicine,

Department of Neuroscience, Trondheim, Norway

Full list of author information is available at the end of the article
}

predictor of mortality than conventional risk factors for CVD [6]. McAuley and Blair [7] recently pointed out reduced cardiorespiratory fitness as a greater health threat than obesity and suggested that more emphasis should be put on increasing $\mathrm{VO}_{2 \text { peak }}$. This might be especially important considering that higher levels of $\mathrm{VO}_{2 \text { peak }}$ seems to attenuate or eliminate the increased health risk associated with obesity [8]. Findings from the epidemiological Nord-Trøndelag Health Study (the HUNT Study) demonstrate that physical active people with a clustering of cardiovascular risk factors appears to have comparable risk of premature death as inactive individuals without risk factors [9]. In the same cohort men with $\mathrm{VO}_{2 \text { peak }}$ below $44.2 \mathrm{ml} \cdot \mathrm{kg}^{-1} \cdot \mathrm{min}^{-1}$ were eight times more likely to have a cluster of CVD risk factors, compared to men above $50.5 \mathrm{ml} \cdot \mathrm{kg}^{-1} \cdot \mathrm{min}^{-1}$ [10].

Results from the Aerobics Center Longitudional Study further suggest that people with low $\mathrm{VO}_{2 \text { peak }}$ is

\section{C) Biomed Central}


characterized by depressive symptoms and low emotional well being [11]. High levels of $\mathrm{VO}_{2 \text { peak }}$ are associated with high levels of quality of life (QOL) [12]. Body mass index (BMI) are found inversely related to QOL in patients with schizophrenia [3] but the relation between $\mathrm{VO}_{2 \text { peak }}$ and perceived QOL are not evaluated.

Objective measures of $\mathrm{VO}_{2 \text { peak }}$ have rarely been presented in patients with schizophrenia. The classical study by Carlson et al. [13] were the first to describe oxygen uptake in patients with schizophrenia, but many of their patients did not reach values close to maximal oxygen uptake. Our research group revealed significant changes in $\mathrm{VO}_{2 \text { peak }}$ after eight weeks of high aerobic intensity training in patients with schizophrenia [14]. Recently, Strassnig et al. [3] published measures of oxygen uptake in 117 patients with schizophrenia that were exceedingly low (4.4 metabolic equivalents $\approx 15.4 \mathrm{ml} \cdot \mathrm{kg}$ $\left.{ }^{1} \cdot \mathrm{min}^{-1}\right)$. This $\mathrm{VO}_{2 \text { peak }}$ value are much lower than the $\mathrm{VO}_{2}$ required for walking in patients with schizophrenia [14], and at a level that may indicate a need for heart transplant in heart failure patients [15].

The primary aim of this study was to evaluate objectively measured $\mathrm{VO}_{2 \text { peak }}$ during walking or running in men and women with schizophrenia compared to $\mathrm{VO}_{2 \text { peak }}$ in healthy individuals from the Nord-Trøndelag Health Study (HUNT). We hypothesized that patients with schizophrenia had reduced $\mathrm{VO}_{2 \text { peak }}$ compared to normative healthy individuals. The secondary aim was to evaluate relationships between $\mathrm{VO}_{2 \text { peak }}$, risk factors for cardiovascular disease, and quality of life.

\section{Methods}

\section{Subjects}

We included 33 patients, 11 women and 22 men, with ICD-10 schizophrenia, schizotypal or delusional disorders (F20 to F29) in the study. Patients were in- and out-patients at a University hospital and had agreed to take part in exercise interventions studies. All patients were under antipsychotic medical treatment. 24 patients were smokers. Exclusion criteria were known coronary artery disease, known chronic obstructive pulmonary disease, and not being able to perform physical treadmill testing and exercise. Patients were examined by a physician at inclusion to the study and the exclusion criterions were confirmed by medical records.

\section{Assessments}

An individualized protocol was applied to measure $\mathrm{VO}_{2 \text { peak }}$ and peak heart rate $\left(\mathrm{HR}_{\text {peak }}\right)$, using the Cortex Metamax II portable metabolic test system (Cortex Biophysik GmbH, Leipzig, Germany) and the Polar S610i heart rate monitor (Polar Electro, Finland), respectively. The protocol has previously been described in patients with schizophrenia as well as in healthy individuals $[14,16]$.
The patients were carefully familiarized with the test procedures and the treadmill when entering the laboratory. Warm-up was ten minute walking or running on the treadmill at an intensity corresponding to $60-70 \%$ $\mathrm{HR}_{\text {peak }}$. The test started from warm-up speed (with minimum 5\% inclination) after which the speed or the inclination was increased every minute $\left(0.5-1 \mathrm{~km} \cdot \mathrm{h}^{-1}\right.$ and $1-2 \%$, respectively) to a level that brought the patient to exhaustion. The highest oxygen uptake and heart rate $(\mathrm{HR})$ recorded during the last minute of the test were determined as $\mathrm{VO}_{2 \text { peak }}$ and $\mathrm{HR}_{\text {peak }}$, respectively. $\mathrm{VO}_{2 \text { peak }}$ where also presented as $\mathrm{ml} \cdot \mathrm{kg}^{-0.75} \cdot \mathrm{min}^{-1}$ to normalise for the differences in bodyweight between the patients [17].

We compared the patients $\mathrm{VO}_{2 \text { peak }}$ with age and sex specific strata from the Nord-Trøndelag Health Study (the HUNT Study) [10]. The HUNT study is an epidemiological study of the general population in the neighbouring county to the university hospital. The HUNT Fitness study tested $\mathrm{VO}_{2 \text { peak }}$ in 4.631 healthy individuals (20 to 90 years) using mixing chamber gas-analyzer ergospirometry (Cortex MetaMax II, Cortex, Leipzig, Germany) and an individualised protocol that has close resemblance to the protocol used in the present study. $14.1 \%$ of the participants reported to be inactive, defined as no activity or exercising less than once per week. For each patient with schizophrenia, we estimated a normative $\mathrm{VO}_{2 \text { peak }}$, namely the mean value defined in the HUNT Fitness study strata for the corresponding sex and age. We titled the $\mathrm{VO}_{2 \text { peak }}$ estimated from sex and age strata independent of physical activity level, as HUNT general. The $\mathrm{VO}_{2 \text { peak }}$ from age and sex strata for healthy inactive men and women were titled HUNT inactive. The percent of HUNT general and HUNT inactive $\mathrm{VO}_{2 \text { peak }}$ was calculated as: (achieved $\mathrm{VO}_{2 \text { peak }} \div$ age predicted $\left.\mathrm{VO}_{2 \text { peak }}\right) \cdot 100$.

In the HUNT Fitness study men and women below $44.2 \mathrm{ml} \cdot \mathrm{kg}^{-1} \cdot \mathrm{min}^{-1}$ and $35.1 \mathrm{ml} \cdot \mathrm{kg}^{-1} \cdot \mathrm{min}^{-1}$, respectively, were associated with higher cardiovascular risk factor profile [10]. The same $\mathrm{VO}_{2 \text { peak }}$ values were used as threshold values when evaluating conventional CVD risk factors.

Morning fasting blood levels were taken. Serum glucose was analysed using Reflotron Plus system (Roche Diagnostics, Mannheim, Germany). HDL (high-densitylipoprotein) cholesterol, total cholesterol and triglyceride concentrations in serum were measured using a Modular P chemistry analyzer (Roche Diagnostics, Mannheim, Germany). LDL cholesterol was calculated using the Friedewald equation [18]. BP (blood pressure) was measured using a Maxi-Stabil 3 (Welch Allyn, Jungingen, Germany). Patients were sitting and had rested for at least 5 minutes. Risk factors were classified as follows: hypertension, diastolic pressure $\geq 90 \mathrm{mmHg}$ and/or 
systolic pressure $\geq 140 \mathrm{mmHg}$; elevated blood glucose, > $6.0 \mathrm{mmol} \cdot \mathrm{L}^{-1}$; elevated total cholesterol, $>6.1 \mathrm{mmol} \cdot \mathrm{L}^{-1}$ in patients $<30$ years old, $>6.9 \mathrm{mmol} \cdot \mathrm{L}^{-1}$ in patients $30-49$ years old and $>7.8 \mathrm{mmol} \cdot \mathrm{L}^{-1}$ in patients $\geq 50$ years old; elevated LDL-cholesterol, $4.3>\mathrm{mmol} \cdot \mathrm{L}^{-1}$ in patients $<30$ years old, $4.7>\mathrm{mmol} \cdot \mathrm{L}^{-1}$ in patients $30-49$ years old and $>5.3 \mathrm{mmol} \cdot \mathrm{L}^{-1}$ in patients $\geq 50$ years old; reduced $\mathrm{HDL}$-cholesterol, $<1.0 \mathrm{mmol} \cdot \mathrm{L}^{-1}$; elevated triglyceride, $>2.6 \mathrm{mmol} \cdot \mathrm{L}^{-1}$; obesity, $\mathrm{BMI} \geq 30.0 \mathrm{~kg} \cdot \mathrm{m}^{-1}$ $[19,20]$.

The short form (SF-36) was used to assess the physical health and mental health aspects of health related quality of life [21]. SF-36 consists of eight sub scores and can also be divided into a physical component score (PCS) and mental component score (MCS). 0 reflect the poorest health whereas 100 reflect the best health.

The Positive and Negative Syndrome Scale (PANSS) was used to evaluate the severity of symptoms of schizophrenia [22]. PANSS constitutes three scales measuring positive (productive symptoms), negative symptoms (deficit features) and general severity of illness. A total of 30 items are evaluated on a likert scale ranging from 1 (absent) to 7 (extreme) and added up to a total score as well as the three sub scores. In this study we used the positive and negative sub scores (7 items each) as well as the total score (30 items).

\section{Analyses}

We used the independent samples T-test to compare differences between men and women, between patients below and above the $\mathrm{VO}_{2 \text { peak }}$ thresholds as well as between measured $\mathrm{VO}_{2 \text { peak }}$ and HUNT general and HUNT inactive $\mathrm{VO}_{2 \text { peak }}$. We used the Pearson chisquare test to detect whether there was a significant association between patients above/below the $\mathrm{VO}_{2 \text { peak }}$ threshold and prevalence of risk factors. We calculated the odds ratio for having one or more risk factors in the patients below threshold. The analysis was adjusted for age and sex. In multiadjusted analysis we also adjusted for the potential cofounding effect of smoking.

We used Pearson $r$ to analyse correlations between $\mathrm{VO}_{2 \text { peak }}\left(\mathrm{ml} \cdot \mathrm{kg}^{-0.75} \cdot \mathrm{min}^{-1}\right)$ and each domain of the SF-36. The significance level $(\alpha)$ was set at $p<0.05$ (2-tailed). Data are described as mean and standard deviation (SD), unless otherwise noted. SPSS statistical package, version 18.0 (SPSS Inc.), was applied to analyse results.

The study was approved by the regional committees for medical and health research ethics, middle Norway and conducted according to the Helsinki declaration. Written informed consent was obtained from all the included patients after the procedures were fully explained.

\section{Results}

\section{Demographics}

Age was $33.7 \pm 10.4$ years and $35.9 \pm 11.5$ years in men and women, respectively. The total PANSS, total positive PANSS and total negative PANSS score was $65 \pm$ $17,15 \pm 6$ and $17 \pm 8$ in men, and $68 \pm 23,16 \pm 6$ and $18 \pm 8$ in women, respectively.

\section{Peak oxygen uptake}

The $\mathrm{VO}_{2 \text { peak }}$ for the men and women with schizophrenia are presented in Table 1 . Individual $\mathrm{VO}_{2 \text { peak }}$ values are plotted against age as well as normative $\mathrm{VO}_{2 \text { peak }}$ strata from the HUNT Fitness study in Figure 1. $\mathrm{VO}_{2 \text { peak }}$ in the men with schizophrenia was $84 \pm 21 \%$ of age predicted HUNT inactive $(\mathrm{p}<0.001)$ and $74 \pm 19 \%$ of HUNT general $(\mathrm{p}<0.001)$. The $\mathrm{VO}_{2 \text { peak }}$ in the women with schizophrenia was not different from HUNT inactive $(101 \pm 28 \%)$ and HUNT general (89 \pm $25 \%$; n.s.). Age predicted $\mathrm{VO}_{2 \text { peak }}$ was $44.5 \pm 2.9$ in HUNT inactive men, $50.3 \pm 4.1 \mathrm{ml} \cdot \mathrm{kg}^{-1} \cdot \mathrm{min}^{-1}$ in HUNT general men, $35.2 \pm 1.8$ in HUNT inactive women and $40.0 \pm 3.2 \mathrm{ml} \cdot \mathrm{kg}^{-1} \cdot \mathrm{min}^{-1}$ in HUNT general women.

\section{Conventional risk factors}

Risk factor assessment was lost in one male patient. Risk factors were present in 24 of 32 patients and of these five were above and 19 were below the thresholds. Among the eight patients without risk factors, six were above and two were below the thresholds $\left(\chi^{2}=7.6, \mathrm{df}=\right.$ $1, \mathrm{p}=0.006)$. Based on the odds ratio adjusted for age and sex patients were 24.2 (95\% CI $=1.5-505.6)$ times more likely to have one or more risk factors if they were below the $\mathrm{VO}_{2 \text { peak }}$ threshold. When we also adjusted for smoking the odds ratio was 28.3 (95\% CI = 1.6-505.6). Among the patients below the $\mathrm{VO}_{2 \text { peak }}$ thresholds 10 patients had hypertension, 11 elevated glucose, 12 reduced HDL-cholesterol, 11 elevated triglyceride and 14 had obesity. Above the thresholds 2 patients had hypertension, 2 elevated glucose and 1 was obese. There were 8 smokers above the thresholds and 16 below. Differences in mean levels are presented in Table 2.

\section{Quality of life}

Results from the SF-36 questionnaire and correlations between SF-36 variables and $\mathrm{VO}_{2 \text { peak }}$ are presented in Table 3.

\section{Discussion \\ Peak oxygen uptake}

The present results highlight reduced $\mathrm{VO}_{2 \text { peak }}$ as a major risk factor for CVD in patients suffering from schizophrenia. The $\mathrm{VO}_{2 \text { peak }}$ was $37.1 \pm 9.2$ and $35.6 \pm$ $10.7 \mathrm{ml} \cdot \mathrm{kg}^{-1} \cdot \mathrm{min}^{-1}$ in men and women, respectively. 
Table 1 Individual characteristics from the peak oxygen uptake test

\begin{tabular}{|c|c|c|c|c|c|c|c|c|}
\hline Patient & Age & BW & $\mathrm{VO}_{2 \text { peak }}$ & $\mathrm{VO}_{2 \text { peak }}$ & $\mathrm{VO}_{2 \text { peak }}$ & $V_{E}$ & RER & HR \\
\hline $\mathrm{nr}$ & years & $\mathrm{Kg}$ & $L \cdot \min ^{-1}$ & $\mathrm{ml} \cdot \mathrm{kg}^{-1} \cdot \mathrm{min}^{-1}$ & $\mathrm{ml} \cdot \mathrm{kg}^{-0.75} \cdot \mathrm{min}^{-1}$ & $L \cdot \mathrm{min}^{-1}$ & & Beats $\cdot \mathrm{min}^{-1}$ \\
\hline \multicolumn{9}{|l|}{ Men } \\
\hline 1 & 21 & 76.5 & 3.64 & 47.6 & 140.7 & 126.1 & 1.07 & 186 \\
\hline 2 & 21 & 95.3 & 3.72 & 39.1 & 122.0 & 107.7 & 1.09 & 175 \\
\hline 3 & 24 & 66.6 & 3.65 & 54.9 & 156.6 & 138.1 & 1.19 & 211 \\
\hline 4 & 25 & 159.5 & 4.25 & 26.6 & 94.7 & 134.0 & 1.19 & 154 \\
\hline 5 & 25 & 120.9 & 3.21 & 26.5 & 88.0 & 115.8 & 1.09 & 160 \\
\hline 6 & 26 & 65.0 & 3.15 & 48.5 & 137.6 & 100.4 & 1.22 & 185 \\
\hline 7 & 26 & 107.9 & 4.07 & 37.7 & 121.6 & 126.3 & 1.23 & 177 \\
\hline 8 & 27 & 96.7 & 3.50 & 36.1 & 113.5 & 102.4 & 1.11 & 186 \\
\hline 9 & 27 & 107.2 & 3.36 & 31.3 & 100.9 & 94.7 & 1.04 & 180 \\
\hline 10 & 28 & 100.6 & 2.96 & 29.4 & 93.2 & 69.2 & 1.00 & 190 \\
\hline 11 & 29 & 66.7 & 2.99 & 44.8 & 128.1 & 121.7 & 1.13 & 183 \\
\hline 12 & 31 & 78.0 & 3.76 & 48.2 & 143.3 & 118.6 & 1.41 & 188 \\
\hline 13 & 31 & 70.1 & 3.14 & 44.8 & 129.6 & 106.9 & 1.10 & 165 \\
\hline 14 & 37 & 114.0 & 3.87 & 34.0 & 110.9 & 109.2 & 1.10 & 153 \\
\hline 15 & 40 & 98.7 & 2.38 & 24.1 & 76.0 & 65.2 & 1.00 & 143 \\
\hline 16 & 41 & 77.4 & 3.29 & 42.0 & 126.1 & 110.4 & 1.21 & 153 \\
\hline 17 & 41 & 89.5 & 3.80 & 42.5 & 130.6 & 105.7 & 1.22 & 164 \\
\hline 18 & 41 & 117.1 & 3.88 & 33.1 & 109.0 & 118.6 & 1.06 & 165 \\
\hline 19 & 45 & 122.3 & 3.38 & 27.7 & 91.9 & 125.4 & 1.08 & 150 \\
\hline 20 & 47 & 122.7 & 2.94 & 24.0 & 79.7 & 89.2 & 1.00 & 153 \\
\hline 21 & 50 & 75.7 & 3.46 & 45.7 & 134.8 & 90.8 & 1.08 & 156 \\
\hline 22 & 58 & 109.6 & 3.07 & 28.1 & 90.6 & 91.2 & 1.07 & 160 \\
\hline Mean \pm SD & $33.7 \pm 10.4$ & $97.2 \pm 24.0$ & $3.43 \pm 0.44$ & $37.1 \pm 9.2$ & $114.5 \pm 22.6$ & $107.6 \pm 19.0$ & $1.12 \pm 0.10$ & $170 \pm 17$ \\
\hline \multicolumn{9}{|l|}{ Women } \\
\hline 1 & 22 & 61.7 & 2.98 & 48.3 & 135.4 & 94.1 & 1.18 & 180 \\
\hline 2 & 24 & 53.3 & 2.28 & 42.8 & 115.6 & 54.0 & 0.99 & 173 \\
\hline 3 & 28 & 66.4 & 2.82 & 42.6 & 121.2 & 97.1 & 1.14 & 169 \\
\hline 4 & 28 & 73.5 & 2.33 & 31.7 & 92.8 & 66.4 & 1.20 & 176 \\
\hline 5 & 28 & 80.3 & 2.44 & 30.4 & 91.0 & 93.0 & 1.20 & 188 \\
\hline 6 & 34 & 51.6 & 2.61 & 50.7 & 135.6 & 79.8 & 1.27 & 194 \\
\hline 7 & 41 & 144.5 & 2.46 & 17.0 & 59.0 & 71.0 & 1.02 & 150 \\
\hline 8 & 42 & 75.5 & 3.30 & 43.7 & 128.8 & 108.0 & 1.20 & 163 \\
\hline 9 & 44 & 64.9 & 1.98 & 30.5 & 86.6 & 56.0 & 1.16 & 175 \\
\hline 10 & 48 & 55.5 & 1.70 & 30.7 & 83.6 & 73.2 & 1.10 & 168 \\
\hline 11 & 58 & 91.8 & 2.12 & 23.1 & 71.5 & 74.1 & 1.13 & 151 \\
\hline Mean \pm SD & $35.9 \pm 11.5$ & $74.5 \pm 26.3$ & $2.46 \pm 0.46$ & $35.6 \pm 10.7$ & $101.9 \pm 26.6$ & $78.8 \pm 17.4$ & $1.15 \pm 0.08$ & $172 \pm 14$ \\
\hline
\end{tabular}

$\mathrm{BW}$, body weight; $\mathrm{VO}_{2 \text { peak, }}$ peak oxygen uptake; $\mathrm{HR}$, heart rate; $\mathrm{V}_{\mathrm{E}}$, total pulmonary ventilation; RER, respiratory exchange ratio; $S \mathrm{D}$, standard deviation

These values are considerable higher than previous assumptions [3,13]. Strassnig et al. [3] reported $\mathrm{VO}_{2}$ values of $18.7 \pm 6.8$ and $13.4 \pm 4.6 \mathrm{ml} \cdot \mathrm{kg}^{-1} \cdot \mathrm{min}^{-1}$ in the men and women, respectively (mean age of $45.1 \pm 10.1$ years). These low $\mathrm{VO}_{2 \text { peak }}$ values is to some degree explained by the high body weight (mean BMI of $36.7 \pm$ $7.5 \mathrm{~m} \cdot \mathrm{kg}^{2}$ ). However, there are some indications of an underrating of these patients' $\mathrm{VO}_{2 \text { peak }}$. First, the patients only reached a low peak heart rate $\left(142 \pm 21\right.$ beats. min ${ }^{-}$ $\left.{ }^{1}\right)$. Secondly, both Carlsson et al. [13] and Strassnig et al. [3] applied a cycle ergometer test which is known to depend more on the patients motivation than a treadmill test. Patients with schizophrenia terminate cycle tests already at submaximal work loads, in contrast to health subjects [23]. Thirdly, subjects tested on a cycle ergometer achieve $7-16 \%$ lower $\mathrm{VO}_{2 \max }$ compared with a maximal treadmill test, even when $\mathrm{HR}_{\text {peak }}$ is not significantly different $[24,25]$.

In contrast to Strassnig et al. [3], the present results demonstrate that the mean $\mathrm{VO}_{2 \text { peak }}$ in the women was similar to the men with schizophrenia, even though the age was similar (36 years in women versus 34 years in 


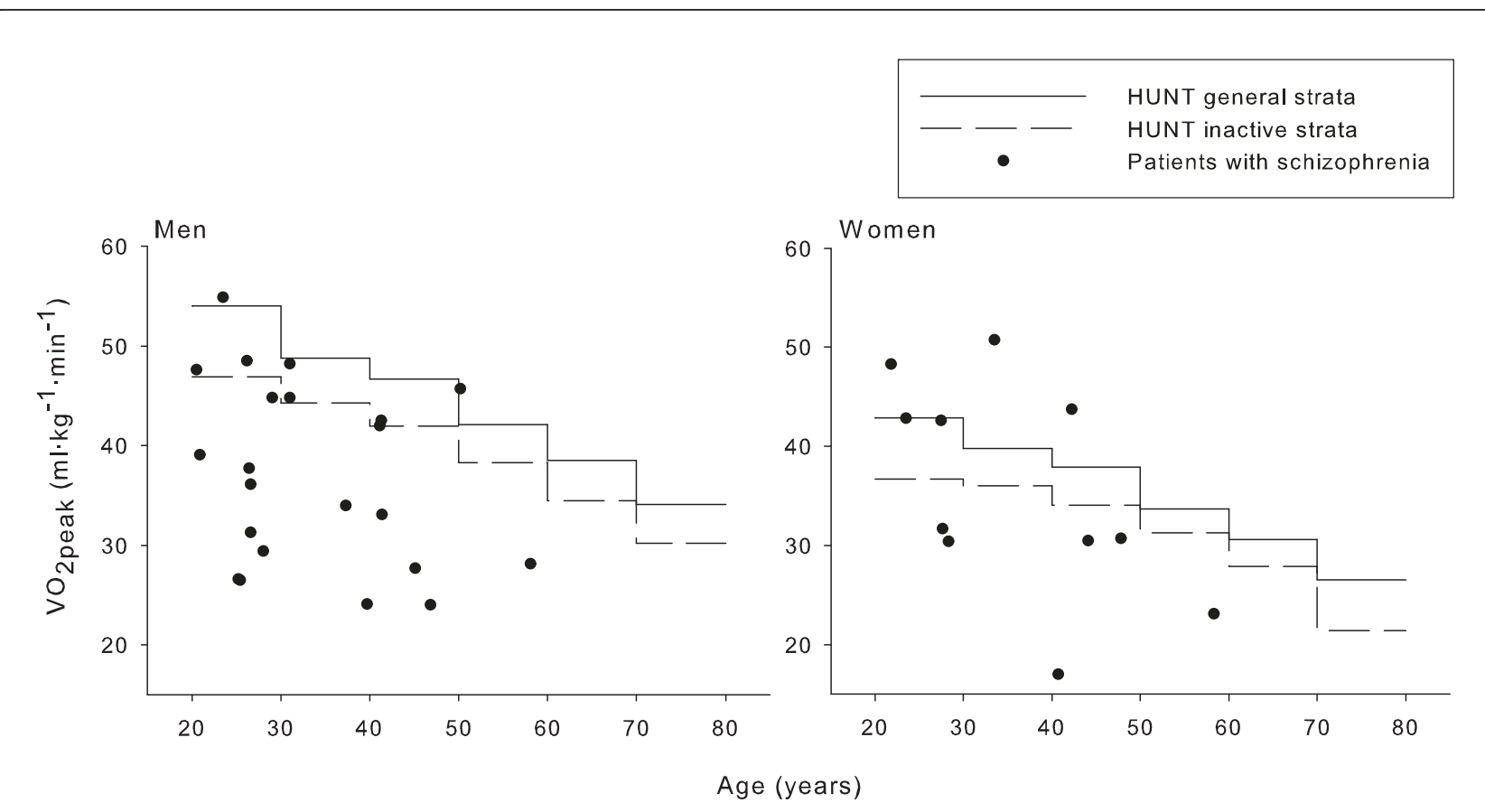

Figure 1 Peak oxygen uptake in patients with schizophrenia and normative healthy men and women. Normative strata are adopted from the HUNT fitness study [10]. HUNT general strata are age and sex specific strata regardless of physical activity level.

men). Women normally have about $10 \mathrm{ml} \cdot \mathrm{kg}^{-1} \cdot \mathrm{min}^{-1}$ lower $\mathrm{VO}_{2 \text { peak }}$ compared to men at the same age [10]. The mean body weight was 97.2 and $74.5 \mathrm{~kg}$ in men and women, respectively, which partially explain the difference in $\mathrm{VO}_{2 \text { peak }}$.

\section{Comparison with healthy individuals}

The comparison with normalised $\mathrm{VO}_{2 \text { peak }}$ from the HUNT Fitness study, confirm our hypothesis that $\mathrm{VO}_{2 \text { peak }}$ is reduced in men with schizophrenia. The $\mathrm{VO}_{2 \text { peak }}$ in the women with schizophrenia was almost identical (101\%) to inactive healthy HUNT women. Even lower $\mathrm{VO}_{2 \text { peak }}$ in men with schizophrenia compared to normative inactive men might suggest that more than just inactivity contribute the reduced $\mathrm{VO}_{2 \text { peak }}$. The $\mathrm{VO}_{2 \text { peak }}$ in the men with schizophrenia is similar to normative healthy men aged 60-69 years [10]. In other words, the $\mathrm{VO}_{2 \text { peak }}$ in the men with schizophrenia is comparable to healthy men that are about 30 years older. Patients with schizophrenia actually have 15-25 years shorter life expectancy than the general population $[26,27]$. It is noteworthy that the $\mathrm{VO}_{2 \text { peak }}$ presented in the HUNT Fitness study is somewhat higher than previous described populations with regard to objectively measured $\mathrm{VO}_{2 \text { peak }}[28-31]$.

\section{Cardiovascular risk}

People with reduced $\mathrm{VO}_{2 \text { peak }}$ are consistently being associated with increased risk of cardiovascular and allcause mortality. Kodama et al. [5] found that $3.5 \mathrm{ml} \cdot \mathrm{kg}^{-}$ ${ }^{1} \cdot \mathrm{min}^{-1}$ (1 MET) increases were associated with $13 \%$ and $15 \%$ reductions in all-cause mortality and CVD/coronary heart disease, respectively. Aspenes et al. [10] found that $5 \mathrm{ml} \cdot \mathrm{kg}^{-1} \cdot \mathrm{min}^{-1}$ lower $\mathrm{VO}_{2 \text { peak }}$ correspond to $56 \%$ higher odds of having a cluster of cardiovascular risk factors.

The comparison of patients with schizophrenia below and above the $\mathrm{VO}_{2 \text { peak }}$ thresholds suggested by Aspenes et al. [10] confirm that patients below these thresholds have higher prevalence of risk factors compared with patients above the thresholds. Based on the odds ratio patients were 28.3 times more likely to have one or more risk factors if they were below the $\mathrm{VO}_{2 \text { peak }}$ thresholds. When comparing mean levels above and below thresholds, all risk factors, except glucose, was better in the patients above the thresholds. These findings suggest a strong connection between the patients $\mathrm{VO}_{2 \text { peak }}$ and the conventional risk factors for CVD, as confirmed in other populations [10,32].

Our data are not quite consistent with findings from US suggesting that especially women with schizophrenia are at high risk of developing metabolic syndrome [33]. 
Table 2 Characteristics ${ }^{a}$ in patients below and above the threshold peak oxygen uptake $\left(\mathrm{VO}_{2 \text { peak }}\right)^{\mathrm{b}}$

\begin{tabular}{|c|c|c|c|}
\hline & \multicolumn{3}{|c|}{ Men } \\
\hline & $\mathrm{VO}_{2 \text { peak }}(<44.2)(n=15)$ & $\mathrm{VO}_{2 \text { peak }}(\geq 44.2)(n=6)$ & Mean difference $(95 \% \mathrm{Cl})$ \\
\hline Systolic pressure (mm Hg) & $139.4 \pm 16.8$ & $125.7 \pm 11.0$ & $-13.8(-29.6$ to 2.0$)$ \\
\hline Diastolic pressure (mm Hg) & $87.4 \pm 7.0$ & $84.3 \pm 5.0$ & $-3.0(-9.7$ to 3.6$)$ \\
\hline Total cholesterol $\left(\mathrm{mmol} \cdot \mathrm{L}^{-1}\right)$ & $5.2 \pm 0.7$ & $4.5 \pm 0.5$ & $-0.7(-1.3$ to -0.0$)$ \\
\hline HDL cholesterol $\left(\mathrm{mmol} \cdot \mathrm{L}^{-1}\right)$ & $1.0 \pm 0.3$ & $1.6 \pm 0.4$ & $0.5(0.2$ to 0.9$)$ \\
\hline LDL cholesterol $\left(\mathrm{mmol} \cdot \mathrm{L}^{-1}\right)$ & $3.2 \pm 0.6$ & $2.5 \pm 0.6$ & $-0.7(-1.3$ to -0.1$)$ \\
\hline Triglyceride $\left(\mathrm{mmol} \cdot \mathrm{L}^{-1}\right)$ & $2.1 \pm 1.1$ & $0.9 \pm 0.2$ & $-1.2(-1.8$ to -0.6$)$ \\
\hline Glucose $\left(m m o l \cdot L^{-1}\right)$ & $6.4 \pm 2.0$ & $5.8 \pm 0.6$ & $-0.6(-2.4$ to 1.1$)$ \\
\hline \multirow[t]{3}{*}{$\mathrm{BMI}\left(\mathrm{kg} \cdot \mathrm{m}^{-2}\right)$} & $33.0 \pm 5.5$ & $23.6 \pm 2.4$ & $-9.5(-14.5$ to -4.5$)$ \\
\hline & \multicolumn{3}{|c|}{ Women } \\
\hline & $\mathrm{VO}_{\text {2peak }}(<35.1)(\mathrm{n}=6)$ & $\operatorname{VO}_{\text {2peak }}(\geq 35.1)(n=5)$ & \\
\hline Systolic pressure (mm Hg) & $121.6 \pm 7.9$ & $103.8 \pm 11.9$ & $-17.8(-32.6$ to -3.0$)$ \\
\hline Diastolic pressure (mm Hg) & $80.8 \pm 4.4$ & $68.8 \pm 8.8$ & $-12(-22.1$ to -1.9$)$ \\
\hline Total cholesterol $\left(\mathrm{mmol} \cdot \mathrm{L}^{-1}\right)$ & $5.0 \pm 0.7$ & $4.6 \pm 1.0$ & $-0.4(-1.5$ to 0.8$)$ \\
\hline HDL cholesterol $\left(\mathrm{mmol} \cdot \mathrm{L}^{-1}\right)$ & $1.3 \pm 0.3$ & $1.8 \pm 0.3$ & $0.5(0.1$ to 0.9$)$ \\
\hline LDL cholesterol $\left(\mathrm{mmol} \cdot \mathrm{L}^{-1}\right)$ & $2.9 \pm 0.9$ & $2.5 \pm 1.1$ & $-0.4(-1.8$ to 1.0$)$ \\
\hline Triglyceride $\left(\mathrm{mmol} \cdot \mathrm{L}^{-1}\right)$ & $1.8 \pm 0.7$ & $0.8 \pm 0.3$ & $-1.0(-1.7$ to -0.3$)$ \\
\hline Glucose $\left(\mathrm{mmol} \cdot \mathrm{L}^{-1}\right)$ & $6.1 \pm 1.5$ & $4.8 \pm 0.4$ & $-1.3(-2.9$ to 0.2$)$ \\
\hline \multirow[t]{3}{*}{$\mathrm{BMI}\left(\mathrm{kg} \cdot \mathrm{m}^{-2}\right)$} & $31.2 \pm 10.9$ & $23.6 \pm 4.5$ & $-7.5(-19.5$ to 4.4$)$ \\
\hline & \multicolumn{3}{|c|}{ All } \\
\hline & $\begin{array}{l}<\text { threshold } \\
(n=21)\end{array}$ & $\begin{array}{l}\geq \text { threshold } \\
(n=11)\end{array}$ & \\
\hline Systolic pressure (mm Hg) & $134.7 \pm 16.8$ & $115.7 \pm 15.7$ & $-19.0(-31.8$ to -6.3$)$ \\
\hline Diastolic pressure $(\mathrm{mm} \mathrm{Hg})$ & $85.63 \pm 6.9$ & $77.3 \pm 10.4$ & $-8.4(-14.9$ to -1.9$)$ \\
\hline Total cholesterol $\left(\mathrm{mmol} \cdot \mathrm{L}^{-1}\right)$ & $5.1 \pm 0.7$ & $4.6 \pm 0.7$ & $-0.6(-1.1$ to -0.0$)$ \\
\hline HDL cholesterol $\left(\mathrm{mmol} \cdot \mathrm{L}^{-1}\right)$ & $1.1 \pm 0.3$ & $1.6 \pm 0.3$ & $0.5(0.0$ to 0.1$)$ \\
\hline LDL cholesterol $\left(\mathrm{mmol} \cdot \mathrm{L}^{-1}\right)$ & $3.1 \pm 0.7$ & $2.5 \pm 0.8$ & $-0.6(-1.2$ to -0.1$)$ \\
\hline Triglyceride $\left(\mathrm{mmol} \cdot \mathrm{L}^{-1}\right)$ & $2.0 \pm 1.0$ & $0.9 \pm 0.3$ & $-1.1(-1.6$ to -0.7$)$ \\
\hline Glucose $\left(m m o l \cdot L^{-1}\right)$ & $6.3 \pm 1.8$ & $5.3 \pm 0.7$ & $-1.0(-2.2$ to 0.2$)$ \\
\hline BMI $\left(\mathrm{kg} \cdot \mathrm{m}^{-2}\right)$ & $32.4 \pm 7.5$ & $23.6 \pm 3.3$ & $-8.8(-13.7$ to -3.9$)$ \\
\hline
\end{tabular}

${ }^{a}$ mean \pm SD.

${ }^{\mathrm{b}} 44.2 \mathrm{ml} \cdot \mathrm{kg}^{-1} \cdot \mathrm{min}^{-1}$ in men and 35.1 in women based on the results from Aspenes et al. [10].

$\mathrm{HDL}$, high-density lipoprotein; LDL, low-density lipoprotein; BMI, body mass index.

Table 3 SF-36 items scores ${ }^{a}$ and Pearson correlation coefficient between SF-36 items and peak oxygen uptake ${ }^{b}$

\begin{tabular}{lllllll}
\hline & \multicolumn{2}{c}{ Women (N = 11) } & \multicolumn{2}{c}{ Men (N = 19) } & \multicolumn{2}{c}{ All (N = 30) } \\
\hline SF-36 items & Mean \pm SD & $r$ & Mean \pm SD & $r$ & Mean \pm SD & $r$ \\
\hline Physical function (PF) & $76.4 \pm 28.1$ & $0.68^{*}$ & $82.6 \pm 20.2$ & $0.48^{*}$ & $80.3 \pm 23.1$ & $0.58^{* * *}$ \\
Role physical (RP) & $56.8 \pm 35.5$ & $0.61^{*}$ & $67.1 \pm 30.1$ & 0.10 & $63.3 \pm 32.0$ & 0.34 \\
Bodily pain (BP) & $77.5 \pm 24.7$ & 0.06 & $73.8 \pm 26.1$ & 0.11 & $75.2 \pm 25.2$ & 0.26 \\
General health (GH) & $58.1 \pm 17.6$ & $0.72^{*}$ & $63.6 \pm 19.9$ & 0.42 & $61.6 \pm 19.0$ & $0.53^{* *}$ \\
Vitality (VT) & $52.7 \pm 22.8$ & $0.71^{*}$ & $51.8 \pm 18.6$ & 0.30 & $52.2 \pm 19.9$ & $0.47^{*}$ \\
Social function (SF) & $51.1 \pm 29.8^{\dagger}$ & 0.41 & $74.3 \pm 17.4$ & 0.34 & $65.8 \pm 25.9$ & $0.41^{*}$ \\
Role emotional (RE) & $42.4 \pm 33.7^{\dagger}$ & 0.39 & $73.7 \pm 37.8$ & 0.25 & $62.2 \pm 38.9$ & 0.35 \\
Mental health (MH) & $55.3 \pm 15.1$ & $0.68^{*}$ & $67.0 \pm 16.5$ & 0.08 & $62.7 \pm 16.7$ & 0.34 \\
Physical component (PCS) & $49.1 \pm 10.3$ & $0.72^{*}$ & $48.2 \pm 7.6$ & 0.37 & $48.6 \pm 8.6$ & $0.51^{* *}$ \\
Mental component (MCS) & $36.5 \pm 8.4^{+}$ & 0.52 & $45.6 \pm 10.2$ & 0.16 & $42.2 \pm 10.4$ & 0.34 \\
\hline
\end{tabular}

${ }^{\mathrm{a}}$ Patients with schizophrenia

${ }^{\mathrm{b}} \mathrm{ml} \cdot \mathrm{kg}^{-0.75} \cdot \mathrm{min}^{-1}$.

${ }^{*} p<0.05,{ }^{* *} p<0.005,{ }^{* *} p<0.001$ Pearsons $r .{ }^{+} p<0.05$ compared to men, independent T-test. 
This is most likely caused by the women's fitness level in the present study, as $\mathrm{VO}_{2 \text { peak }}$ have been described as a strong independent predictor of metabolic syndrome [32].

These results emphasize that evaluation of $\mathrm{VO}_{2 \text { peak }}$ should be incorporated into routine clinical practice for risk prediction. The prognostic value of $\mathrm{VO}_{2 \text { peak }}$ is beyond that predicted from other conventional risk factors $[6,34]$. Even in individuals with present risk factors, the higher levels of $\mathrm{VO}_{2 \text { peak }}$ seem to confer a significant protective effect [4]. Reduced $\mathrm{VO}_{2 \text { peak }}$ is a modifiable risk factor, and eight weeks aerobic high intensity interval training has provided significant improvements of $\mathrm{VO}_{2 \text { peak }}$ both in healthy populations [16] and in patients with schizophrenia [14]. Furthermore, to reduce the risk of CVD, the interventions are probably more dependent on improving $\mathrm{VO}_{2 \text { peak }}$ than increasing physical activity level alone $[35,36]$.

\section{Quality of life}

Our findings of lower SF-36 social function, role emotion and mental component score among women than among men might reflect a sex difference in the general population. Lower scores for women than for men have been identified in normative adults [37]. The genderspecific correlations between items of SF-36 and $\mathrm{VO}_{2 \text { peak }}$ suggest major gender differences in self-perception. Only the correlation with between SF-36 physical functioning and $\mathrm{VO}_{2 \text { peak }}$ was significant in men, whereas six correlations with the SF-36 were significant in women. In all subjects together the $\mathrm{VO}_{2 \text { peak }}$ correlated with the patient's perception of physical function, general health, vitality, social function, and physical component score. With some exceptions, these findings are consistent with correlations between SF-36 variables and BMI in patients with schizophrenia [38]. In line with Strassnig et al. [38] we found a significant correlation with the physical component score but not the mental component score, suggesting that reduced $\mathrm{VO}_{2 \text { peak }}$ mainly is perceived as a physical health problem, not mental. Contrary, both the mental and physical health components of QOL are found related to estimated $\mathrm{VO}_{2 \text { peak }}$ in healthy men [12]. An interesting note is, however, that the patients with lower $\mathrm{VO}_{2 \text { peak }}$ seemed to experience lower vitality and social functioning. Sedentary people are associated with greater risk of low vitality [39]. QOL are found to improve in a dose dependent manner in sedentary women when increasing physical activity level [40].

\section{Limitations}

There are some limitations of the study. First, the sample size is low. Secondly, the patients were included in the study based on request to take part in exercise intervention studies. However, all eligible patients at the department were asked to participate in these studies. Thirdly, severe ill patients with schizophrenia, with poor insight to their illness, might have difficulties to evaluate their perception of QOL.

\section{Conclusions}

Men with schizophrenia have lower $\mathrm{VO}_{2 \text { peak }}$ than men in the general population. Patients with a $\mathrm{VO}_{2 \text { peak }}$ below $44.2 \mathrm{ml} \cdot \mathrm{kg}^{-1} \cdot \mathrm{min}^{-1}$ (men) and $35.1 \mathrm{ml} \cdot \mathrm{kg}^{-1} \cdot \mathrm{min}^{-1}$ (women) have higher odds of having one or more risk factors for cardiovascular disease. Low $\mathrm{VO}_{2 \text { peak }}$ compromise patients' perceived physical health. $\mathrm{VO}_{2 \text { peak }}$ should be regarded as least as important as the conventional risk factors for CVD and evaluation of $\mathrm{VO}_{2 \text { peak }}$ should be incorporated in clinical practice. Finally, these finding represent an urging need for developing effective physical training interventions for patients with schizophrenia.

\section{Acknowledgements}

Thanks to the patients that volunteered to take part.

\section{Author details}

${ }^{1}$ Norwegian University of Science and Technology, Faculty of Medicine, Department of Neuroscience, Trondheim, Norway. ${ }^{2}$ St. Olavs University Hospital, Division of Psychiatry, Department of Research and Development (AFFU), Trondheim, Norway. ${ }^{3}$ St. Olavs University Hospital, Division of Psychiatry, Department of Østmarka, Trondheim, Norway. ${ }^{4}$ Norwegian University of Science and Technology, Faculty of Medicine, Department of Circulation and Medical Imaging, Trondheim, Norway. ${ }^{5}$ St.Olavs University Hospital, Department of Physical Medicine and Rehabilitation, Trondheim, Norway. ${ }^{6}$ Hokksund Medical Rehabilitation Centre, Hokksund, Norway. ${ }^{7}$ Telemark University College, Department of Sports and Outdoor Life Studies, Bø, Norway.

\section{Authors' contributions}

$\mathrm{GM}, J \mathrm{H}, J \mathrm{H}$ and $\mathrm{JH}$ designed the study. $\mathrm{JH}$ and GEN recruited patients, performed $\mathrm{VO}_{2 \text { peak }}$ testing and other data acquisition. $\mathrm{GM}$ and $\mathrm{JH}$ undertook the statistical analysis and $\mathrm{JH}$ wrote the first draft of the paper. All authors have contributed to and have approved the final manuscript.

\section{Competing interests}

The authors declare that they have no competing interests.

Received: 4 May 2011 Accepted: 5 December 2011

Published: 5 December 2011

\section{References}

1. Brown S, Kim M, Mitchell C, Inskip H: Twenty-five year mortality of a community cohort with schizophrenia. Br J Psychiatry 2010, 196:116-121.

2. Osby U, Correia N, Brandt L, Ekbom A, Sparen P: Mortality and causes of death in schizophrenia in Stockholm county, Sweden. SchizophrRes 2000, 45:21-28.

3. Strassnig M, Brar JS, Ganguli R: Low cardiorespiratory fitness and physical functional capacity in obese patients with schizophrenia. Schizophr Res 2011, 126:103-109.

4. Blair SN, Kampert JB, Kohl HW, Barlow CE, Macera CA, Paffenbarger RS Jr, Gibbons LW: Influences of cardiorespiratory fitness and other precursors on cardiovascular disease and all-cause mortality in men and women. JAMA 1996, 276:205-210.

5. Kodama S, Saito K, Tanaka S, Maki M, Yachi Y, Asumi M, Sugawara A, Totsuka K, Shimano H, Ohashi Y, Yamada N, Sone H: Cardiorespiratory fitness as a quantitative predictor of all-cause mortality and 
cardiovascular events in healthy men and women: a meta-analysis. JAMA 2009, 301:2024-2035.

6. Myers J, Prakash M, Froelicher V, Do D, Partington S, Atwood JE: Exercise capacity and mortality among men referred for exercise testing. $N$ Engl J Med 2002, 346:793-801.

7. McAuley PA, Blair SN: Obesity paradoxes. J Sports Sci 2011, 29:773-782.

8. Lee S, Kuk JL, Katzmarzyk PT, Blair SN, Church TS, Ross R: Cardiorespiratory fitness attenuates metabolic risk independent of abdominal subcutaneous and visceral fat in men. Diabetes Care 2005, 28:895-901.

9. Tjonna AE, Lund Nilsen TI, Slordahl SA, Vatten L, Wisloff U: The association of metabolic clustering and physical activity with cardiovascular mortality: the HUNT study in Norway. J Epidemiol Community Health 2010, 64:690-695.

10. Aspenes ST, Nilsen TI, Skaug EA, Bertheussen GF, Ellingsen O, Vatten L, Wisloff U: Peak oxygen uptake and cardiovascular risk factors in 4,631 healthy women and men. Med Sci Sports Exerc 2011, 43:1465-1473.

11. Galper DI, Trivedi MH, Barlow CE, Dunn AL, Kampert JB: Inverse association between physical inactivity and mental health in men and women. Med Sci Sports Exerc 2006, 38:173-178.

12. Sloan RA, Sawada SS, Martin CK, Church T, Blair SN: Associations between cardiorespiratory fitness and health-related quality of life. Health Qual Life Outcomes 2009, 7:47.

13. Carlsson C, Dencker SJ, Grimby G, Haggendal J: Circulatory studies during physical exercise in mentally disordered patients. I. Effects of large doses of chlorpromazine. Acta Med Scand 1968, 184:499-509.

14. Heggelund J, Nilsberg GE, Hoff J, Morken G, Helgerud J: Effects of high aerobic intensity training in patients with schizophrenia-A controlled trial. Nord J Psychiatry 2011, 65:269-275.

15. Myers J, Gullestad L, Vagelos R, Do D, Bellin D, Ross H, Fowler MB: Cardiopulmonary exercise testing and prognosis in severe heart failure: $14 \mathrm{~mL} / \mathrm{kg} / \mathrm{min}$ revisited. Am Heart J 2000, 139:78-84.

16. Helgerud J, Hoydal K, Wang E, Karlsen T, Berg P, Bjerkaas M, Simonsen T, Helgesen C, Hjorth N, Bach R, Hoff J: Aerobic High-Intensity Intervals Improve VO2max More Than Moderate Training. Med Sci Sports Exerc 2007, 39:665-671.

17. Rogers DM, Olson BL, Wilmore JH: Scaling for the VO2-to-body size relationship among children and adults. J Appl Physiol 1995, 79:958-967.

18. Friedewald WT, Levy RI, Fredrickson DS: Estimation of the concentration of low-density lipoprotein cholesterol in plasma, without use of the preparative ultracentrifuge. Clin Chem 1972, 18:499-502.

19. Mancia G, De Backer G, Dominiczak A, Cifkova R, Fagard R, Germano G, Grassi G, Heagerty AM, Kjeldsen SE, Laurent S, Narkiewicz K, Ruilope L, Rynkiewicz A, Schmieder RE, Boudier HA, Zanchetti A, Vahanian A, Camm J, De Caterina R, Dean V, Dickstein K, Filippatos G, Funck-Brentano C, Hellemans I, Kristensen SD, McGregor K, Sechtem U, Silber S, Tendera M, Widimsky P, Zamorano JL, Erdine S, Kiowski W, Agabiti-Rosei E,

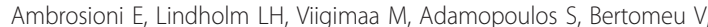
Clement D, Farsang C, Gaita D, Lip G, Mallion JM, Manolis AJ, Nilsson PM, O'Brien E, Ponikowski P, Redon J, Ruschitzka F, Tamargo J, van Zwieten P, Waeber B, Williams B: 2007 Guidelines for the Management of Arterial Hypertension: The Task Force for the Management of Arterial Hypertension of the European Society of Hypertension (ESH) and of the European Society of Cardiology (ESC). J Hypertens 2007, 25:1105-1187.

20. Sernyak MJ: Implementation of monitoring and management guidelines for second-generation antipsychotics. J Clin Psychiatry 2007, 68:14-18.

21. Ware JE, Kosinski M, Gandek B: SF-36 health survey: manual \& interpretation guide Lincoln, RI: QualityMetric Inc; 2000.

22. Kay SR, Fiszbein A, Opler LA: The positive and negative syndrome scale (PANSS) for schizophrenia. Schizophr Bull 1987, 13:261-276.

23. Deimel H, Lohmann S: Physical capacity of schizophrenic patients. Rehabilitation (Stuttg) 1983, 22:81-85.

24. Hermansen L, Saltin B: Oxygen uptake during maximal treadmill and bicycle exercise. J Appl Physiol 1969, 26:31-37.

25. Myers J, Buchanan N, Walsh D, Kraemer M, McAuley P, Hamilton-Wessler M, Froelicher VF: Comparison of the ramp versus standard exercise protocols. J Am Coll Cardiol 1991, 17:1334-1342.

26. Hennekens $\mathrm{CH}$, Hennekens AR, Hollar D, Casey DE: Schizophrenia and increased risks of cardiovascular disease. Am Heart J 2005, 150:1115-1121.

27. Tiihonen J, Lonnqvist J, Wahlbeck K, Klaukka T, Niskanen L, Tanskanen A, Haukka J: 11-year follow-up of mortality in patients with schizophrenia: a population-based cohort study (FIN11 study). Lancet 2009, 374:620-627.
28. Jackson AS, Beard EF, Wier LT, Ross RM, Stuteville JE, Blair SN: Changes in aerobic power of men, ages 25-70 yr. Med Sci Sports Exerc 1995, 27:113-120.

29. Jackson AS, Wier LT, Ayers GW, Beard EF, Stuteville JE, Blair SN: Changes in aerobic power of women, ages 20-64 yr. Med Sci Sports Exerc 1996, 28:884-891.

30. Talbot LA, Metter EJ, Fleg JL: Leisure-time physical activities and their relationship to cardiorespiratory fitness in healthy men and women 1895 years old. Med Sci Sports Exerc 2000, 32:417-425.

31. Morris CK, Myers J, Froelicher VF, Kawaguchi T, Ueshima K, Hideg A: Nomogram based on metabolic equivalents and age for assessing aerobic exercise capacity in men. J Am Coll Cardiol 1993, 22:175-182.

32. Lakka TA, Laaksonen DE, Lakka HM, Mannikko N, Niskanen LK, Rauramaa R, Salonen JT: Sedentary lifestyle, poor cardiorespiratory fitness, and the metabolic syndrome. Med Sci Sports Exerc 2003, 35:1279-1286.

33. McEvoy JP, Meyer JM, Goff DC, Nasrallah HA, Davis SM, Sullivan L, Meltzer HY, Hsiao J, Scott Stroup T, Lieberman JA: Prevalence of the metabolic syndrome in patients with schizophrenia: baseline results from the Clinical Antipsychotic Trials of Intervention Effectiveness (CATIE) schizophrenia trial and comparison with national estimates from NHANES III. Schizophr Res 2005, 80:19-32.

34. Laukkanen JA, Kurl S, Salonen R, Rauramaa R, Salonen JT: The predictive value of cardiorespiratory fitness for cardiovascular events in men with various risk profiles: a prospective population-based cohort study. Eur Heart J 2004, 25:1428-1437.

35. Blair SN, Cheng Y, Holder JS: Is physical activity or physical fitness more important in defining health benefits? Med Sci Sports Exerc 2001, 33 S379-S399.

36. Lee DC, Sui X, Ortega FB, Kim YS, Church TS, Winett RA, Ekelund U, Katzmarzyk PT, Blair SN: Comparisons of leisure-time physical activity and cardiorespiratory fitness as predictors of all-cause mortality in men and women. Br J Sports Med 2011, 45:504-510.

37. Jenkinson C, Coulter A, Wright L: Short form 36 (SF36) health survey questionnaire: normative data for adults of working age. BMJ 1993, 306:1437-1440.

38. Strassnig M, Brar JS, Ganguli R: Body mass index and quality of life in community-dwelling patients with schizophrenia. Schizophr Res 2003, 62:73-76.

39. Puetz TW: Physical activity and feelings of energy and fatigue: epidemiological evidence. Sports Med 2006, 36:767-780.

40. Martin CK, Church TS, Thompson AM, Earnest CP, Blair SN: Exercise dose and quality of life: a randomized controlled trial. Arch Intern Med 2009, 169:269-278.

Pre-publication history

The pre-publication history for this paper can be accessed here: http://www.biomedcentral.com/1471-244X/11/188/prepub

\section{doi:10.1186/1471-244X-11-188}

Cite this article as: Heggelund et al: Reduced peak oxygen uptake and implications for cardiovascular health and quality of life in patients with schizophrenia. BMC Psychiatry 2011 11:188.

\section{Submit your next manuscript to BioMed Central and take full advantage of:}

- Convenient online submission

- Thorough peer review

- No space constraints or color figure charges

- Immediate publication on acceptance

- Inclusion in PubMed, CAS, Scopus and Google Scholar

- Research which is freely available for redistribution 